\title{
Experimental Research on New Grade of Steel Protective Material for Light Armored Vehicles
}

\author{
Jure Bernetič ${ }^{1, *}$ - Tomaž Vuherer ${ }^{2}$ - Matjaž Marčetič1 - Mladen Vuruna ${ }^{3}$ \\ 1 Acroni Jesenice, d.o.o., Slovenia \\ 2 University of Maribor, Faculty of Mechanical Engineering, Slovenia \\ 3 University of Defense, Military Academy Belgrade, Serbia
}

An investigation of new PROTAC 500 armour steel was conducted. Three plates were heat treated to different states. One was quenched, the second and third were quenched and low temperature tempered at 220 and $280{ }^{\circ} \mathrm{C}$ for 3 hours. A tensile test, hardness measurements, and an instrumented Charpy test were performed. Metallographic was performed by optical microscopy (OM). Ballistic resistances of all three steel plates were measured. The behaviour of steel was tested using armour piercing projectiles $7.62 \times 39 \mathrm{~mm}$ API BZ (former soviet designation for Armor Piercing Incendiary bullet). The best results were obtained in quenched state.

Keywords: armour steel, hardness, instrumented Charpy test, armour piercing projectiles

\section{INTRODUCTION}

The trends of worldwide armour community is currently accelerating efforts to deliver lightweight armour technologies that can defeat armour piercing (AP) projectiles at reduced areal weights and that they are available across a large industrial base [1] to [3]. While many of these programs involve the application of lower density metals, such as aluminium and titanium, the selection of steel alloys is still competitive for many ballistic and structural applications. The ability to produce armour components in both commercial and military operational areas with available equipment and personnel is a major advantage of steel based solutions. To meet these requirements, the worldwide armour community has increased the availability of quenched and tempered armour steels by updating current steel military specifications [4] to [6]. One of those programs is at a steel mill in Acroni Jesenice, Slovenia, where new low heavy weight grade armour steel PROTAC 500, was developed and which is presented in this paper.

\section{MATERIAL}

Three different states of steel were examined. Steel in State A was quenched, steel in State B was quenched and low temperature tempered at $220^{\circ} \mathrm{C}$ for 3 hours, and steel in State $\mathrm{C}$ was quenched and tempered at $280{ }^{\circ} \mathrm{C}$ for 3 hours.

New grade of $8 \mathrm{~mm}$ thick steel plate material, developing as PROTAC 500 (chemical composition is in Table 1) sign, prepared by three different thermal treatment states, is used for this research, Table 2.
Table 1. Chemical composition of PROTAC 500 steel

\begin{tabular}{cccccc}
\hline \multicolumn{6}{c}{ Chemical composition of PROTAC 500 wt.\% } \\
\hline $\mathrm{C}$ & $\mathrm{Si}$ & $\mathrm{Mn}$ & $\mathrm{Cr}$ & $\mathrm{Ni}$ & $\mathrm{Mo}$ \\
\hline 0.3 & 0.7 & 1.2 & 0.8 & 0.7 & 0.35 \\
\hline
\end{tabular}

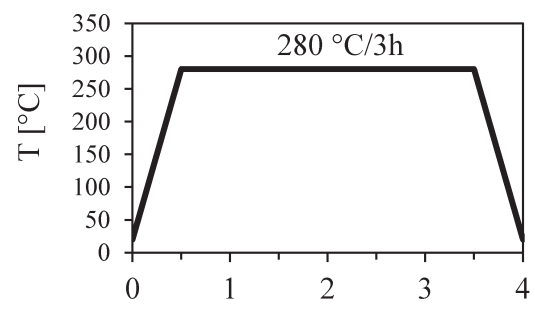

a)

$\mathrm{t}[\mathrm{h}]$

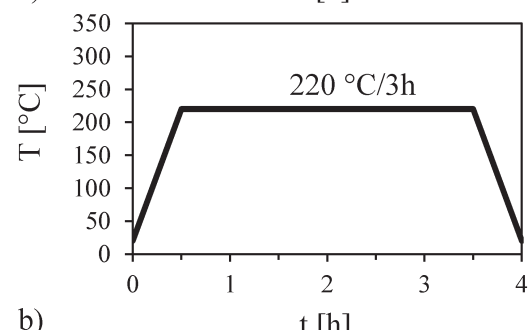

b)

$\mathrm{t}[\mathrm{h}]$

Fig. 1. Heat treatment; a) of State $B$, and b) State $C$

Table 2. States of the testing material PROTAC 500 used in research tests

\begin{tabular}{ccc}
\hline State $\mathrm{A}$ & State $\mathrm{B}$ & State C \\
\hline Water quenched & $\begin{array}{c}\text { Tempered at } 220^{\circ} \mathrm{C} \\
\text { for } 3 \text { hours }\end{array}$ & $\begin{array}{c}\text { Tempered at } 280^{\circ} \mathrm{C} \\
\text { for } 3 \text { hours }\end{array}$ \\
\hline
\end{tabular}

State A was water quenched. States B and C were quenched and tempered. Heat treatment of steel in state B is shown in Fig. 1a. Steel was heated at 220 ${ }^{\circ} \mathrm{C}$ for 3 hours and cooled down in a furnace. Heat 
treatment of steel in state C is shown in Fig. 1b. Steel was heated at $280{ }^{\circ} \mathrm{C}$ for 3 hours and cooled down in a furnace.

\section{EXPERIMENTAL PROCEDURE AND APPROPRIATE EQUIPMENT}

Mechanical and instrumented Charpy tests had been performed before plates in all three states were tested for resistance to armour piercing $7.62 \times 39 \mathrm{~mm}$ API BZ projectiles, on the proofing ground laboratory space.

Specimens for tensile tests were machined from the steel plates. Cylindrical specimens of dimensions shown in Fig. 2 standardized by EN ISO 6892-1:2009 standard [7] were used for testing. Hardness was measured using Vickers pyramid according to EN ISO 6507-4:2005 standard [8] and load of $98.1 \mathrm{~N}$ in three different locations from the upper side of the plate where later the armour piercing has been done. Three hardness measurements were taken at each location.

Charpy tests with ISO V-notch were done according to the ISO 14556 standard [9]. Tests were performed on $10 \times 7.5 \times 55 \mathrm{~mm}$ specimens Fig. 3 using an instrumented and new Vuhi-Charpy software [10]. Tests were performed at temperatures $-40,-20,0$ and $+20{ }^{\circ} \mathrm{C}$.

The VuhiCharpy software controls the Amsler RKP-300 Charpy pendulum and records the data of force and energy from the sensors during the impact. Recording data enables to determine the force versus time diagram. The initial velocity during the impact $\left(v_{0}\right)$ is known from the mass and starting angle of the pendulum. Diagram velocity - time can be determined using Eq. 1.

$$
v(t)=v_{0}-\frac{1}{m} \int_{t_{0}}^{t} v(t) d t
$$

Diagram displacement versus time can be determined using Eq. 2.

$$
s(t)=\frac{1}{m} \int_{t_{0}}^{t} v(t) d t .
$$

Finally, diagram force versus displacement can be drawn. Area below of this diagram represents energy for fracture during the Charpy test. Energy can be calculated using Eq. 3.

$$
E(s)=\int_{s_{0}}^{s} F d s .
$$

Special acoustic sensor on the Charpy pendulum detects when crack starts to propagate. This sensor and SEP1315 standard [9] and [11] enable to split energy for initiation and energy for propagation from the total energy for fracture.
All three states were tested by armour piercing projectiles. $7.62 \times 39 \mathrm{~mm}$ API BZ bullets were used (Fig. 4). Regarding the STANAG 4569 standard [12], the velocity of the projectile has to be $695 \pm 20 \mathrm{~m} / \mathrm{s}$. The velocity was provided by the test rifle barrel with appropriate charge, and measured using two different methods.

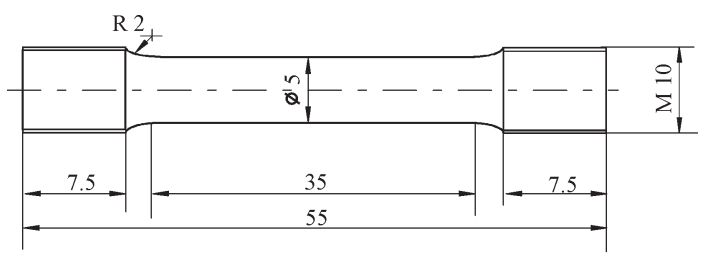

Fig. 2. Specimen for tensile test

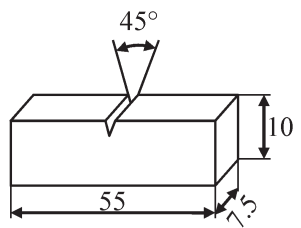

Fig. 3. Specimen for Charpy instrumented tests

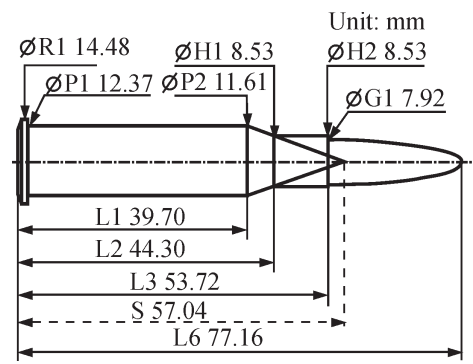

Fig. 4. Bullets $7.62 \times 39 \mathrm{~mm}$ API BZ for ballistic analyses

The first was using a radar (the average velocity of the projectile is assumed by the values of muzzle velocity and velocity of terminal flight phase of the bullet behind the tested plate), The second method of velocity measurements used an optical sensor placed in the terminal phase of the flight path (position of the sensor was 2 meters from test plate). The weapon used for the test was a M82 weapon gun, ranged on the distance of $30 \mathrm{~m}$.

\section{EXPERIMENTAL RESULTS}

\subsection{Tensile Test}

Results of the tensile test are shown in Figs. 5 to 8. Yield stress, tensile strength, elongation and contraction were measured. The yield strength results are presented in Fig. 5. Average values are marked for each plate signed as the $\mathrm{A}, \mathrm{B}$ and $\mathrm{C}$ state as mentioned 
above. The highest values of tensile strengths were in plates of state $\mathrm{C}$.

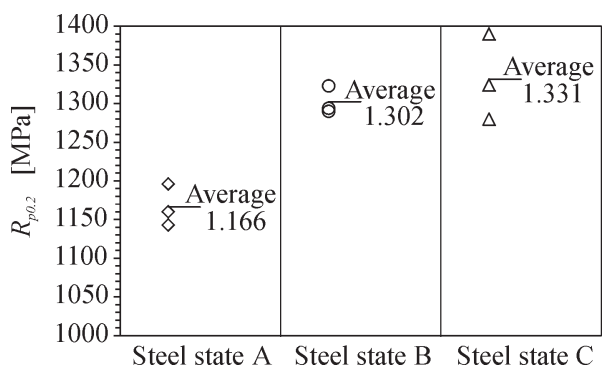

Fig. 5. Yield stress of three different states

The tensile strength $\left(R_{m}\right)$ results are shown in Fig. 6 . The highest tensile strength is in state A and the lowest in state $\mathrm{C}$. The highest $R_{p 0.2} / R_{m}$ ratio is in state A where the value is 0.662 . The highest $R_{p 0.2} / R_{m}$ ratio is on state $\mathrm{C}$ where the value is only 0.806 .

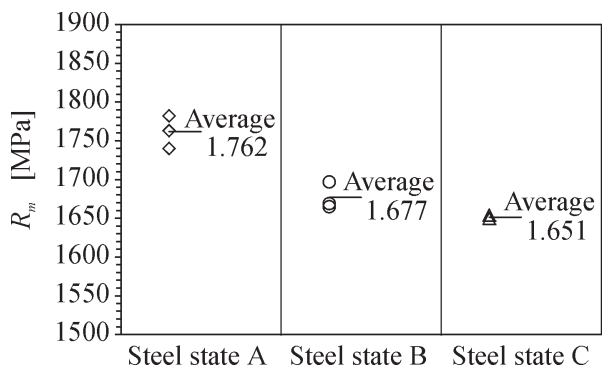

Fig. 6. Tensile strength of three different states

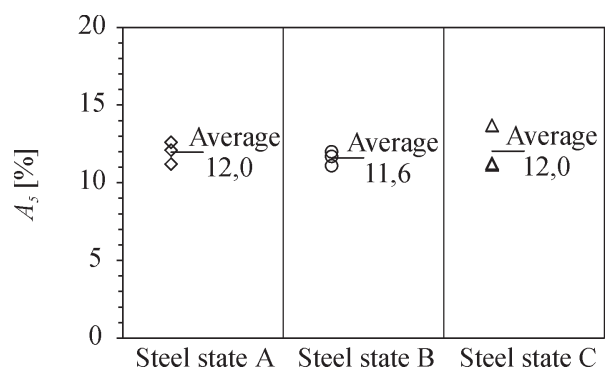

Fig. 7. Elongation of three different states

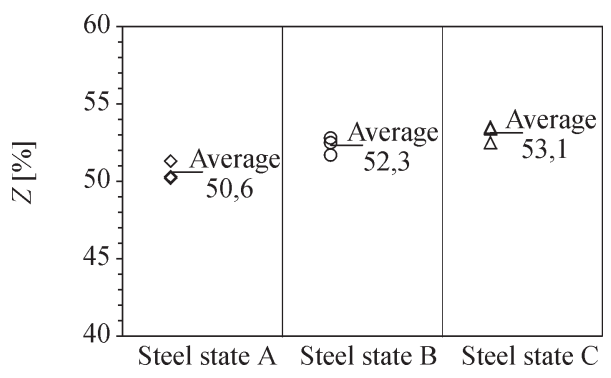

Fig. 8. Contraction of three different states

Elongation of all three states is approximately the same, around 12\%. Results are shown in Fig. 7.
Contraction is highest in state $\mathrm{C}$, which has the highest temperature of the tempering. The lowest contraction is in state A (only quenched).

\subsection{Hardness Results}

Vickers hardness results are shown in Fig. 9. The highest hardness is in state A (only quenched).

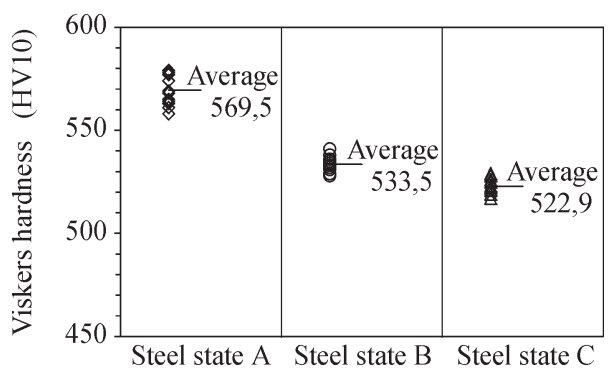

Fig. 9. Vickers hardness results of all three states

Tempering reduces the hardness [13]. Tempering at $220{ }^{\circ} \mathrm{C}$ reduces hardness from 569 to $533 \mathrm{HV} 10$, but tempering at $280{ }^{\circ} \mathrm{C}$ reduces hardness to $525 \mathrm{HV} 10$. The highest scatter of hardness results is in state A.

\subsection{Results of Charpy Test}

The impact toughness of all three states is shown in Fig. 10. The highest impact toughness is in state $\mathrm{B}$ and the lowest is in state $\mathrm{C}$. Tempering at $280{ }^{\circ} \mathrm{C}$ for 3 hours is not appropriate for the material because impact toughness is reduced. On the other hand, tempering at $220{ }^{\circ} \mathrm{C}$ for 3 hours improves impact toughness compared to quenched state.

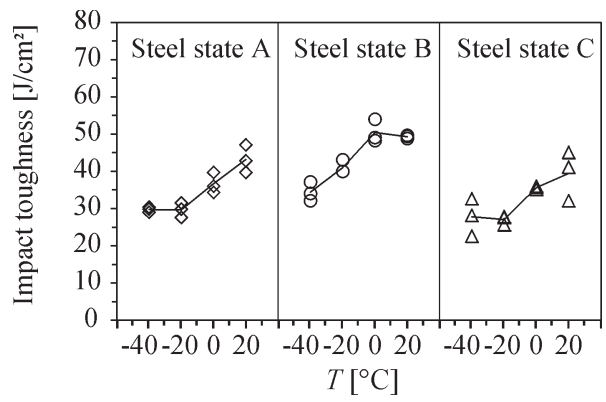

Fig. 10. Impact toughness of three states

Fig. 11 is an example of the results of State $\mathrm{C}$ at $+40{ }^{\circ} \mathrm{C}$. For better armour protection it is important that the material has a higher energy needed for crack initiation, but the energy needed for the start of propagation is also consequential because it gives the material a chance to deform during the impact of the bullet. Figs. 12 to 14 show the total energy needed for 
breakage of the Charpy specimen, energy for crack initiation and crack propagation of all three states.

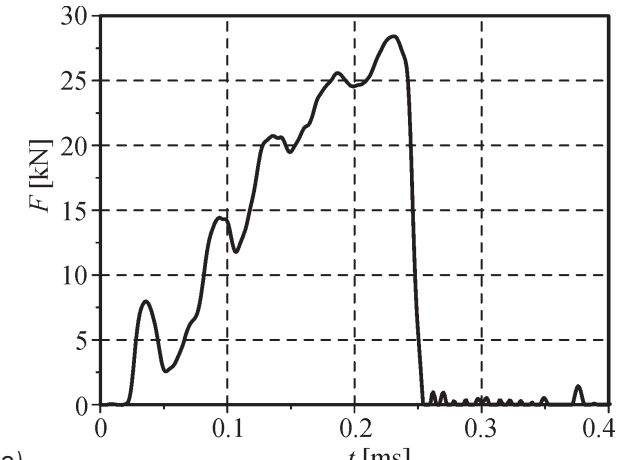

a)

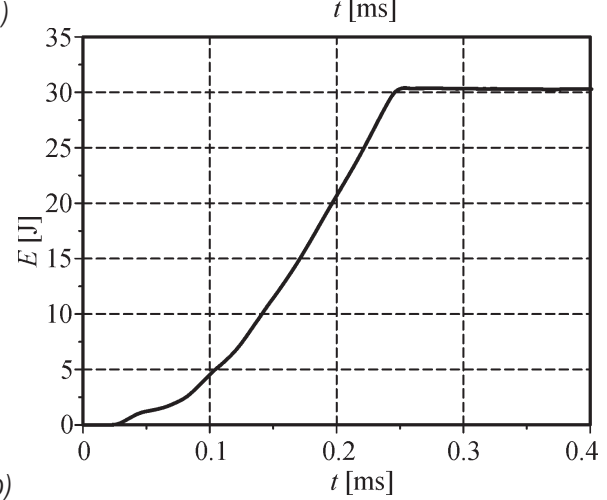

Fig. 11. Instrumented Charpy test results;a) force to time, and b) energy to time; State $\mathrm{C}$ at $+40^{\circ} \mathrm{C}$

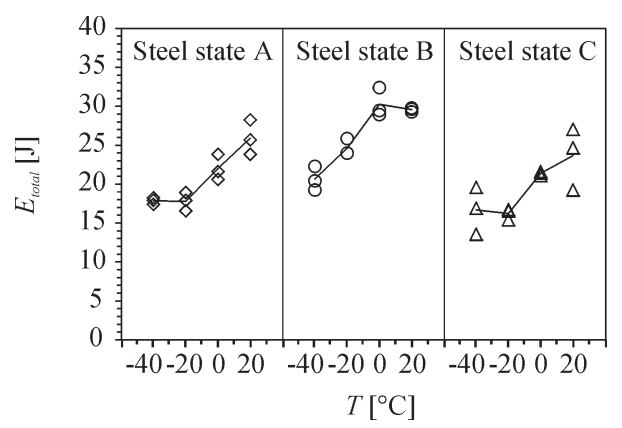

Fig. 12. Total energy of three states

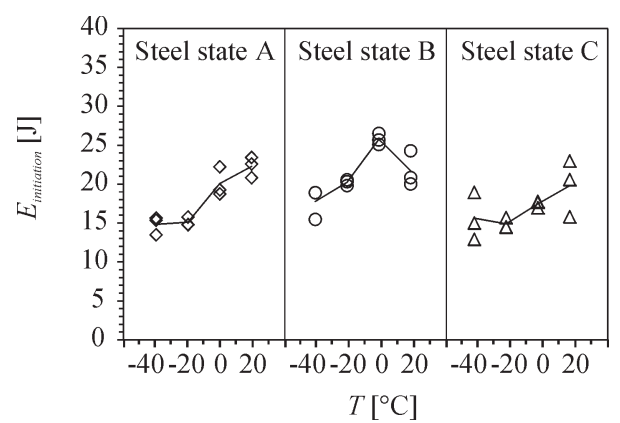

Fig. 13. Energy for initiation of three states

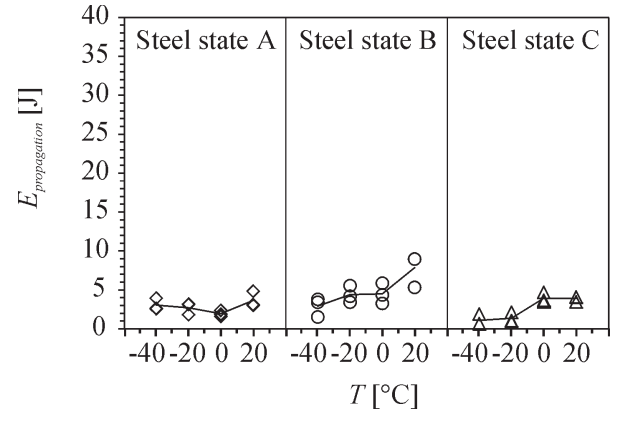

Fig. 14. Energy for propagation of three states

\subsection{Microstructure Analyzes}
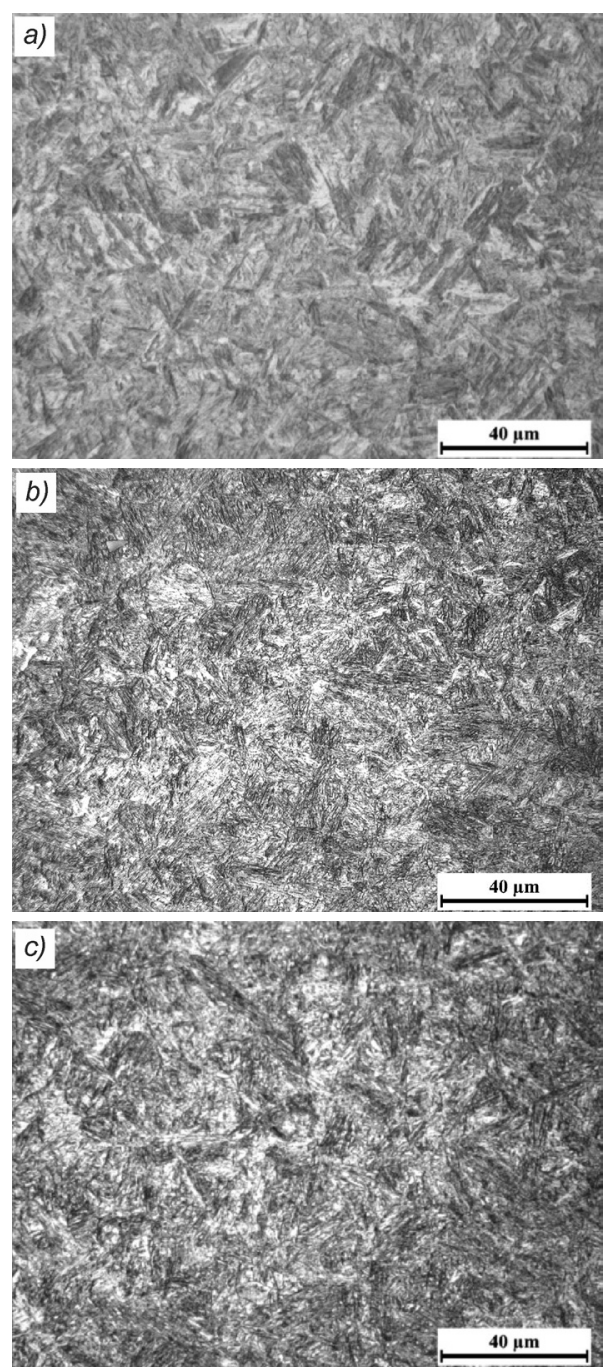

Fig. 15. Microstructures of all three states; a) State $A, b)$ State $B$ and c) State $C$

Microstructures of all three steel states are imagined by Olympus DP $71 \mathrm{CCD}$ camera in the Olypmpus BX $51 \mathrm{M}$ light microscope at magnification of 500× 
at resolution of $1360 \times 1024$ and shown in Fig. 11 . Samples were etched in $3 \%$ nital $\left(3 \% \mathrm{HNO}_{3}\right.$ to $97 \%$ ethyl alcohol).

Fig. 15a shows lath martensite microstructure of the State A which was quenched, while Figs $15 \mathrm{~b}$ and $\mathrm{c}$ are showing the States B and C which were tempered. Lath martensite microstructure and low tempered martensite can be observed in these samples. Low temperature tempering of the martensite microstructure is not used to transform martensite into other microstructure but just for the purpose of residual stress relaxation in the material [13] and [14].

The reduction of the mechanical properties (hardness, impact toughness, tensile strength) of the States B and C can be directly linked to the appearance of the $\varepsilon$ carbide $\left(\mathrm{Fe}_{2.4} \mathrm{C}\right)$ as the consequence of the tempering. Additional research regarding the formation and effect of $\varepsilon$ carbide $\left(\mathrm{Fe}_{2.4} \mathrm{C}\right)$ on mechanical properties will be done in near future using TEM microscopy.

\subsection{Ballistic Resistance Results}

The angle of the test plates was aproximity $90^{\circ}$ to the projectile aproaching direction. Fig. 16 shows a steel plate before and after the ballistic test. Five shots were fired into each plate. All measured bullet velocities were within the limits of the STANAG 4569 standard [12], which is presented in Table 2, for the values measured by radar and optical sensors. The results of the ballistic resistance test are also shown in Table 3. Details of the frontal impact damage of shots 1 and 2 on the State A plate are presented in Fig. 17. No damage can be observed from the back side. Fig. 18 shows the impact damage on the same plate from the front and back side. A smooth bulge can be observed from the rear of the plate.

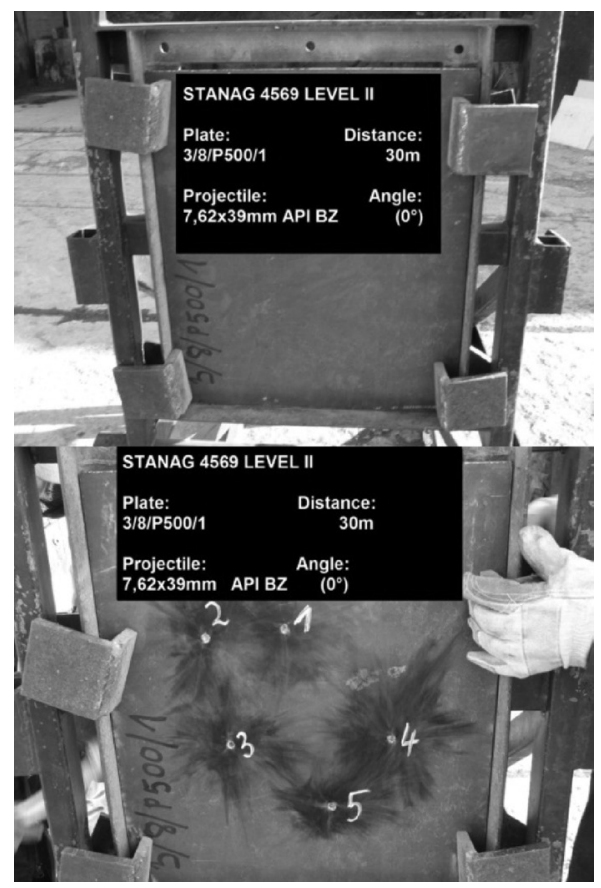

Fig. 16. Test plate before and after the ballistic test

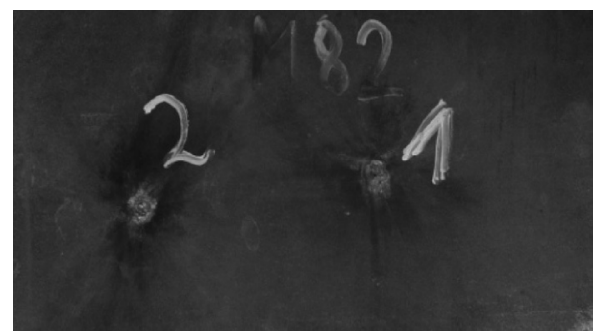

Fig. 17. Details of first and second shots hit damage on State A plate

Table 3. Results of the ballistic resistance of the steel plates

\begin{tabular}{|c|c|c|c|c|c|c|}
\hline State & No. & $\mathrm{V}_{0}[\mathrm{~m} / \mathrm{s}]$ & $\mathrm{V}_{28}[\mathrm{~m} / \mathrm{s}]$ & Angle $\left[{ }^{\circ}\right]$ & Distance [m] & Description of the damage \\
\hline \multirow{5}{*}{ State A } & 1 & 735.6 & 705.0 & 0 & 30 & Deep impression in front, no damage at back \\
\hline & 2 & 737.1 & 707.5 & 0 & 30 & Deep impression in front, no damage at back \\
\hline & 3 & 737.0 & 707.2 & 0 & 30 & Smooth bulge at back \\
\hline & 4 & 731.7 & 701.8 & 0 & 30 & Deep impression in front, no damage at back \\
\hline & 5 & 741.9 & 710.6 & 0 & 30 & Deep impression in front, no damage at back \\
\hline \multirow{5}{*}{ State B } & 1 & 736.4 & 705.8 & 0 & 30 & Bulge at back without crack \\
\hline & 2 & 739.5 & 709.9 & 0 & 30 & Bulge and crack at back, no light penetrating \\
\hline & 3 & 737.6 & 707 & 0 & 30 & Bulge and crack at back, no light penetrating \\
\hline & 4 & 735.2 & 705.6 & 0 & 30 & Bulge and crack at back, no light penetrating \\
\hline & 5 & 736.0 & 706.4 & 0 & 30 & Bulge at back without crack \\
\hline \multirow{5}{*}{ State $\mathrm{C}$} & 1 & 735.1 & 705.7 & 0 & 30 & Crack sufficient to see light trough \\
\hline & 2 & 737.2 & 708 & 0 & 30 & Crack sufficient to see light trough \\
\hline & 3 & 738.6 & 709.6 & 0 & 30 & Complete penetration \\
\hline & 4 & 735.1 & 705.7 & 0 & 30 & Bulge and crack at back, no light penetrating \\
\hline & 5 & 740.5 & 711.9 & 0 & 30 & Complete penetration \\
\hline
\end{tabular}



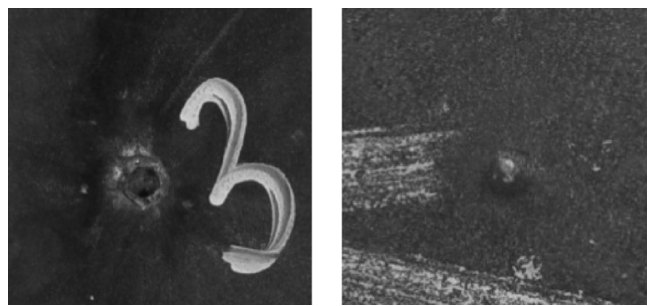

Fig. 18. Details of shot 3 impact damage on state A plate from the front and back side

\section{CONCLUSION}

Ballistic properties are a complex function of yield strength, tensile strength, hardness, ductility, charpy impact energy. An optimum combination of each property is essential for suitable ballistic performance and none of the properites alone are self sufficient to appropriately indicate the ballistic behaviour. Appropriate ballistic performance as a result of good mechanical properties can be achieved by a suitable heat treatment.

Steel in a quenched condition (State A) has the lowest yield stress and highest tensile strength, so $R_{p 0.2} / R_{m}$ ratio is the lowest compared to steels which were quenched and low temperature tempered at $200{ }^{\circ} \mathrm{C}$ (State B) and $280{ }^{\circ} \mathrm{C}$ (State C). Lower values of the $R_{p 0.2} / R_{m}$ ratio indicate enhanced resistance to localised yielding which provides higher ballistic performance.

The highest hardness is in the quenched condition and the lowest in steel state $\mathrm{C}$ (quenched and tempered at $280^{\circ} \mathrm{C}$ ).

The impact toughness of the armour steel is the highest in steel state B but followed closely by the impact toughness of the just quenched condition in state A.

The results of the best ballistic test obtained until today have shown that the highest ballistic resistance of the steel plates was in state A, which has the lowest $R_{p 0.2} / R_{m}$ ratio, the highest hardness, and nearly the highest impact toughness.

Lowered ballistic properties of States B and C can be linked to lowered properties between hardness, $R_{p 0.2} / R_{m}$ ratio and impact thougness and different ration between those properties.

\section{ACKNOWLEDGMENT}

The presented paper has been made within project No 47029 financed by the Ministry of Science and Technology development Republic of Serbia.

\section{REFERENCES}

[1] Baloh, S., Grabulov, V., Sidjanin, L., Pantić, M., Radisavljevic, I. (2010). Geometry, mechanical properties and mounting of perforated plates for ballistic application. Materials and Design, vol. 31, p. 2916-2924, DOI:10.1016/j.matdes.2009.12.031.

[2] Showalter, D., Gooch, W., Burkings, S., Montgomery, J.R.S. (2000). Development and balistic testing of new class of high hardness armor steel. The AMMTIAC Quaterly, vol. 4, no. 4, p. 3-6

[3] Rust, M. (2010). Passive protection Conepts. IBD Deisenroth Engineering, p. 33-37.

[4] Atapek, H.S.S.K. (2011). Ballistic impact behaviour of tempered ballistic steel against $7.62 \mathrm{~mm}$ armour piercing projectile. Defence Science Journal, vol. 61, p. 81-87.

[5] Nahme, H., Lach, E. (1997). Dynamic behaviour of high strength armor steels. Journal de Physique, vol. 7., no. C3, p. 373-378.

[6] Shah Khan, M.Z., Alkemade, S.J., Weston G.M. (1998). Fracture Studies on High Hardness BISALLOY 500 Steel. Melbourne, DSTO-RR-0130.

[7] EN ISO 6892-1:2009 (2009). Metallic materials - Tensile testing - Part 1: Method of test at room temperature. International Organization for Standardization, Geneva.

[8] EN ISO 6507-4:2005 (2005). Metallic materials Vickers hardness test - Part 4: Tables and hardness values), International Organization for Standardization, Geneva.

[9] ISO 14556:2000(E) (2000). Steel Charpy V-notch pendulum impact test - instrumented test method, ), International Organization for Standardization, Geneva.

[10] Vuherer, T. (2008). Analyze of microdefects on strenght at fatigue on coarse grain HEZ . University of Maribor, Faculty for Mechanical Engineering. Fakulteta za strojništvo, Maribor. (in Slovene)

[11] STAHL - EISEN - Prüfblätter (SEP) des Vereins Deutscher Eisenhüttenleute, Kerbschlagbiegeversuch mit Ermittlung von Kraft und Weg (1987). Empfehlungen zur Durchführung und Auswertung, SEP 1315, Verlag Stahleisen mbH, Düsseldorf.

[12] Nato standard - STANAG 4569 (2004). Protection levels for Occupants af Logistic and Light Armoured Vehicles, NATO, AEP-55.

[13] Smoljan, B., Iljkić, D. (2010). Predictions of mechanical properties of quenched and tempered steel. Strojniški vestnik - Journal of Mechanical Engineering, vol. 56, no. 2, p. 115-120.

[14] Liščić, B., Singer, C. (2010). Prediction of quenchhardness within the whole volume of axially-symmetric workpieces of any shape. Strojniški vestnik - Journal of Mechanical Engineering, vol. 56, no. 2, p. 104-114. 